MAZUR Kateryna Vasylivna - PhD (candidate, economics), As. Prof., Head of The Department of Agrarian Management, Vinnytsia National Agrarian University (21008, Vinnitsia, Pirohova st., 3, kv_mazur@ukr.net).

MOSTENSKA Tetiana Gennadiyivna - PhD (candidate, economics), As. Prof of Agrarian Management Department, Vinnytsia National Agrarian University (21008, Vinnitsia, Pirohova st., 3, mostik_t@ukr.net).

ЛУЦЯК Виталий Васильевич - д.э.н., к.т.н., доц., заведующий кафедры маркетинга и аграрного бизнеса, Винницкий национальный аграрный университет (21021, г. Винница, ул. Келецкая, 94, 69, LutsiakVV@gmail.com).

МАЗУР Екатерина Васильевна - к.э.н., доц. заведующая кафедрой аграрного менеджмента, Винницкий национальный аграрный университет (21008, г. Винница, ул. Пирогова, 3, kv_mazur@ukr.net).

МОСТЕНСКАЯ Татьяна Геннадиевна - к.э.н., доцент кафедры аграрного менеджмента, Винницкий национальный аграрный университет, Винницкий национальный аграрный университет (21008, г. Винница, ул. Пирогова, 3, mostik_t@ukr.net). MOSTENSKA Tetiana Gennadiyivna - PhD (candidate, economics), As. Prof of Agrarian Management Department, Vinnytsia National Agrarian University (21008, Vinnitsia, Pirohova st., 3, mostik t @ $@ u k r . n e t)$.

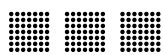

УАК 658.:664.1

DOI: 10.37128/2411-4413-2019-9-7

\section{КОНЦЕПТУАЛЬНІ ПІДХОДИ ДО ФОРМУВАННЯ МАРКЕТИНГОВОЇ СТРАТЕГIÏ ПІДПРИЕМСТВ БУРЯКОЦУКРОВОГО ПІДКОМПЛЕКСУ $\odot$}

КРАСНЯК О.П., кандидат економічних наук, доцент кафедри маркетингу та аграрного бізнесу,

AMOHC C.E., кандидат сільськогосподарських наук, доцент кафедри маркетингу та аграрного бізнесу,

Вінницький національний аграрний університет (м. Вінниця)

У статті розглянуто концептуальні засади розробки та реалізаиії маркетингової стратегії підприємств бурякоиукрового підкомплексу; охарактеризовано етапи формування стратегї; розкрито комплекс економіко-організаційних проблем реалізації стратегічного маркетингового підходу на ринку сільськогосподарської продукиії.

Встановлено, ще вітчизняне иукропереробне виробництво залишається одним із стратегічно важливих напрямів агропромислового комплексу та на сьогодні зберігає перспективи стабілізаиії попри певні проблемні аспекти у розвитку підприємств иукропереробної галузі в иілому.

Представлено основні аспекти формування маркетингової стратегї переробних підприємств; описано зв'язок між фазами розвитку продовольчого маркетингу та рівнем застосування продовольчої маркетингової стратегії. На основі иьього дослідження розроблено комплекс концептуальних підходів маркетингової стратегії підприємства, застосування якого має сприяти забезпеченню систематизованого підходу до ї̈ планування, реалізаиії та контролю.

Результати здійснених досліджень показують, щзо товарна політика підприємств иукробурякового підкомплексу Украӥни повинна бути зорієнтована на постійне покращення якості продукиї як одного із пріоритетних напрямів діяльності иукрового заводу, щьо забезпечує його конкурентні переваги на аграрному ринку. Асортиментна складова передбачає комплексне застосування диверсифікації товарного виробництва иляхом удосконалення наявного асортименту та переробки побічної продукиії. 
На основі аналізу робіт, присвячених особливостям формування маркетингової стратегї переробного підприємства, авторами запропоновано власну інтегральну модель маркетингової стратегії підприємств иукробурякового підкомплексу, яка поєднує товарну, ијінову, комунікаційну та організаційну політику.

Ключові слова: маркетинг, стратегія, політика, цукрові буряки, посівна площа, виробництво, урожайність, ефективність.

Табл.: 1. Рис.: 4. Літ.: 16.

\title{
CONCEPTUAL APPROACHES TO THE FORMATION OF THE MARKETING STRATEGY OF THE BEAUTY SUGAR COMPANY ENTERPRISES
}

\author{
KRASNIAK Olena, \\ Candidate of Economical Science, \\ Associate Professor of the Department of Marketing \\ and Agrarian Business, \\ AMONS Sergey, \\ Candidate of Agricultural Sciences, \\ Associate Professor of the Department of Marketing \\ and Agrarian Business, \\ Vinnitsia National Agrarian University
}

(Vinnitsia)

The conceptual bases of development and realization of marketing strategy of enterprises of beet sugar subcomplex are considered in the article; stages of strategy formation are characterized; the complex of economic and organizational problems of realization of strategic marketing approach in the market of agricultural products is revealed.

It is established that the domestic sugar processing industry remains one of the strategically important directions of the agroindustrial complex and today it preserves the prospects of stabilization despite certain problematic aspects in the development of the enterprises of the sugar processing industry as a whole.

The basic aspects of forming of marketing strategy of processing enterprises are presented; describes the relationship between the phases of food marketing development and the level of application of the food marketing strategy. Based on this research, a set of conceptual approaches of the enterprise marketing strategy was developed, the application of which should contribute to providing a systematic approach to its planning, implementation and control.

The results of the conducted research show that the commodity policy of the sugar beet subcomplex enterprises of Ukraine should be focused on continuous improvement of the quality of production - as one of the priority areas of activity of the sugar plant, which provides its competitive advantages in the agricultural market. The assortment component implies the integrated application of diversification of commodity production by improving the existing assortment and processing of by-products.

On the basis of the analysis of the works devoted to the peculiarities of forming the marketing strategy of the processing enterprise, the authors propose their own integrated model of marketing strategy of the sugar beet subcomplex enterprises, which combines commodity, price, communication and organizational policy.

Key words: marketing, strategy, politics, sugar beet, acreage, production, yield, efficiency.

Tabl.: 1. Fig.: 4. Ref.: 16.

\section{КОНЦЕПТУАЛЬНЫЕ ПОДХОДЫ К ФОРМИРОВАНИЮ МАРКЕТИНГОВОЙ СТРАТЕГИИ ПРЕДПРИЯТИЙ СВЕКЛОСАХАРНОГО ПОДКОМПЛЕКСА}

КРАСНЯК Е.П., кандидат экономических наук, доцент кафедры маркетинга и аграрного бизнеса,

Винницкий национальный аграрный университет

AMOHC C.E., кандидат сельскохозяйственных наук, доцент кафедры маркетинга и аграрного бизнеса,

Винницкий национальной аграрный университет 
В статье рассмотрены кониептуальные основы разработки и реализации маркетинговой стратегии предприятий свеклосахарного подкомплекса; охарактеризованы этапы формирования стратегии; раскрыто комплекс экономико-организационных проблем реализации стратегического маркетингового подхода на рынке сельскохозяйственной продукиии.

Установлено, что отечественное сахароперерабатывающее производство остается одним из стратегически важных направлений агропромышленного комплекса и сегодня сохраняет перспективы стабилизации несмотря на определенные проблемные аспекты в развитии предприятий сахароперерабатьвающей отрасли в целом.

Представлены основные аспекты формирования маркетинговой стратегии перерабатывающих предприятий; описано связь между фазами развития продовольственного маркетинга и уровню применения продовольственной маркетинговой стратегии. На основе этого исследования разработан комплекс концептуальных подходов маркетинговой стратегии предприятия, применение которого должно способствовать обеспечению систематизированного подхода кее планированию, реализачии и контроля.

Результаты проведенных исследований показывают, что товарная политика предприятий свеклосахарного подкомплекса Украины должна быть ориентирована на постоянное улучиение качества продукции - как одного из приоритетных направлений деятельности сахарного завода, обеспечивает его конкурентные преимущества на аграрном рынке. Ассортиментная составляющая предусматривает комплексное применение диверсификации товарного производства путем усовершенствования существующего ассортимента и переработки побочной продукции.

На основе анализа работ, посвященных особенностям формирования маркетинговой стратегии перерабатьвающего предприятия, авторами предложено собственную интегральную модель маркетинговой стратегии предприятий свеклосахарного подкомплекса, которая сочетает товарную, ценовую, коммуникационную и организачионную политику.

Ключевые слова: маркетинг, стратегия, политика, сахарная свекла, посевная площадь, производство, урожайность, эффективность.

Табл.: 1. Рис.: 4. Лит.: 16.

Постановка проблеми. В умовах ринкової економіки, які постійно змінюються, головним завданням сучасного підприємства $\epsilon$ не тільки максимізація прибутку, але і його ефективна маркетингова діяльність.

Стійкі позиції підприємств на ринку досягаються за рахунок вдало обраної стратегії маркетингу, що є запорукою успіху бізнесу. Це та сила, яка дозволяє бізнесу сконцентруватися на роботі, збільшити обсяги продажів, підвищити рентабельність і утримати клієнтів і співробітників порівняно з конкурентами.

Розумне, фахово обгрунтоване маркетингове рішення щодо вибору стратегії дозволить підприємству не тільки зберегти наявні позиції на ринку, вижити у змінному зовнішньому середовищі, а й успішно розвиватися в майбутньому.

Сучасний маркетинг - це, насамперед, теорія і практика прийняття управлінських рішень щодо формування ринково-продуктової стратегії.

Незважаючи на велику кількість підходів до вибору маркетингової стратегії, українські підприємства часто стикаються 3 проблемою формування оптимального стратегічного підходу через низьку адаптованість деяких зарубіжних підходів до вітчизняних умов і високу складність при застосуванні інших.

Проблема формування та реалізації маркетингової стратегії є досить цікавою та потребує подальшого розвитку, адже деякі дослідники надають ій першорядного значення у процесі формування загальної стратегії розвитку підприємства.

Аналіз останніх досліджень і публікацій. Проблемам поняття та оцінки ефективності маркетингової стратегії присвячені праці вчених і практиків: Н.В. Куденко [1], Ж.Ж. Ламбена [2], С.С. Гаркавенко [3], О.С. Анісімова [4], Л.В. Балабанової [5], А.В. Григора [6], А.В. Алферова [7], С.О. Коваль [8], Т.А. Масляк [9], Г.М. Калетніка [16] та ін., проте на сьогодні питання концептуальних підходів до формування маркетингової стратегії підприємств бурякоцукрового підкомплексу залишається досить актуальним та дискусійним.

Формулювання цілей статті. Метою написання статті $є$ обгрунтування концептуальних підходів до формування маркетингової стратегії підприємств бурякоцукрового підкомплексу. 
Виклад основного матеріалу дослідження. Формування та вдосконалення ринкових відносин, а також постійне зростання конкуренції, особливо в кризових умовах господарювання, зумовлює необхідність системного моніторингу й удосконалення усіх складових виробничо-господарської та фінансово-господарської діяльності підприємства. Однією 3 найважливіших складових, яка має вагомий вплив на рівень ефективності функціонування кожного підприємства, є його маркетингова стратегія. Вона зумовлює модель поведінки підприємства на ринку, а, отже, і визначає рівень його сприйняття зовнішнього середовища та встановлення з ним динамічної рівноваги.

Маркетингова стратегія - це програма досягнення найголовнішої мети підприємства забезпечення прибутку від ринкової діяльності; стабільність зростання або скорочення прибутку на угоду зростання інших ринкових показників (капіталізації, глобалізації та ін.). У науковій літературі спостерігається варіативність поглядів на поняття «маркетингова стратегія». Розглянемо більш детально деякі з них.

За визначенням І.К. Беляєвського маркетингова стратегія є комплексом базових рішень та принципів, спрямованих на досягнення генеральної мети підприємства, які виходять 3 оцінки та аналізу ринкової ситуації, можливостей конкурентів та власного потенціалу [10].

Міжнародний словник маркетингових термінів розкриває поняття маркетингова стратегія, як передбачення загальних цілей маркетингових операцій компанії або операцій з просування певного виду продукції або послуг.

Ф. Котлер зазначає, маркетингова стратегія - це маркетингова логіка, за допомогою якої бізнес-одиниця очікує досягнення своїх маркетингових цілей Стратегія повинна бути спрямована на оптимальне використання можливостей компанії і запобігання помилковим діям, які можуть призвести до зниження ефективності його діяльності [11].

Стратегія - складне і потенційно могутнє знаряддя, за допомогою якого сучасна фірма може протистояти умовам, які змінюються. Маркетингова стратегія підприємства - це уніфікований, вичерпний план, який забезпечує виконання головних завдань підприємства» [14].

На думку Ж. Лабмена маркетингова стратегія за своєю суттю - це план реалізації маркетингових заходів, для досягнення поставлених перед компанією цілей [2].

Гаркавенко С.С. [3] стверджує, що при формуванні маркетингової стратегії підприємству необхідно визначити напрями розвитку, конкурентні переваги, що стануть основою стратегії зростання підприємства вцілому. Вони повинні передбачати:

- виділення окремих груп споживачів - сегментування ринку;

- визначення цільових сегментів, на які фірма орієнтуватиме свою діяльність - вибір цільових ринків;

- маркетингове забезпечення товарові бажаного місця на ринку - позиціонування товару на ринку;

- об'єкти особливої уваги - визначення конкурентів-мішеней;

- характеристики й властивості товару вищої якості - визначення конкурентних переваг.

Стратегія маркетингу - це система організаційно-технічних і фінансових заходів щодо інтенсифікації виробництва, реалізації продукції, підвищення іiі конкурентоспроможності, активного впливу на попит та пропозицію. Маркетингова стратегія передбачає контроль за виробництвом і ринком для утримання ринкових цін на рівні, який забезпечує оптимальні прибутки. Маркетингова стратегія втілюється в програмі заходів щодо вдосконалення виробництва та реалізації товарів з метою забезпечення високих і стійких прибутків [4].

Згідно з результатами досліджень Балабанової Л.В. [5], під маркетинговою стратегією вона розуміє принципові, середні і довгострокові рішення, що дають орієнтири і спрямовують окремі заходи маркетингу на досягнення поставлених цілей. Трактує подібне за змістом Алферов А.В., зазначивши, що маркетингова стратегія - це найважливіша функціональна стратегія підприємства, яка є основою розробки загальнофірмової стратегії і бізнес-плану, вона зачіпає всі господарські області і функціональні підсистеми підприємства [7].

Як підкреслює Н. Куденко, вихідними елементами маркетингової стратегії є стратегічні рішення щодо маркетингового міксу, тобто комплексу компонентів маркетингу, який включає чотири складові - товар, ціну, збут та просування (рис. 1).

Григор А.В. [6] зазначає, що «...маркетингова стратегія - це маркетингова логіка, яка забезпечує досягнення ринкових цілей і складається зі спеціальних стратегій щодо цільових сегментів, комплексу маркетингу, рівня маркетингових витрат». 


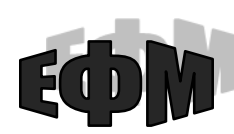

http://efm.vsau.org/

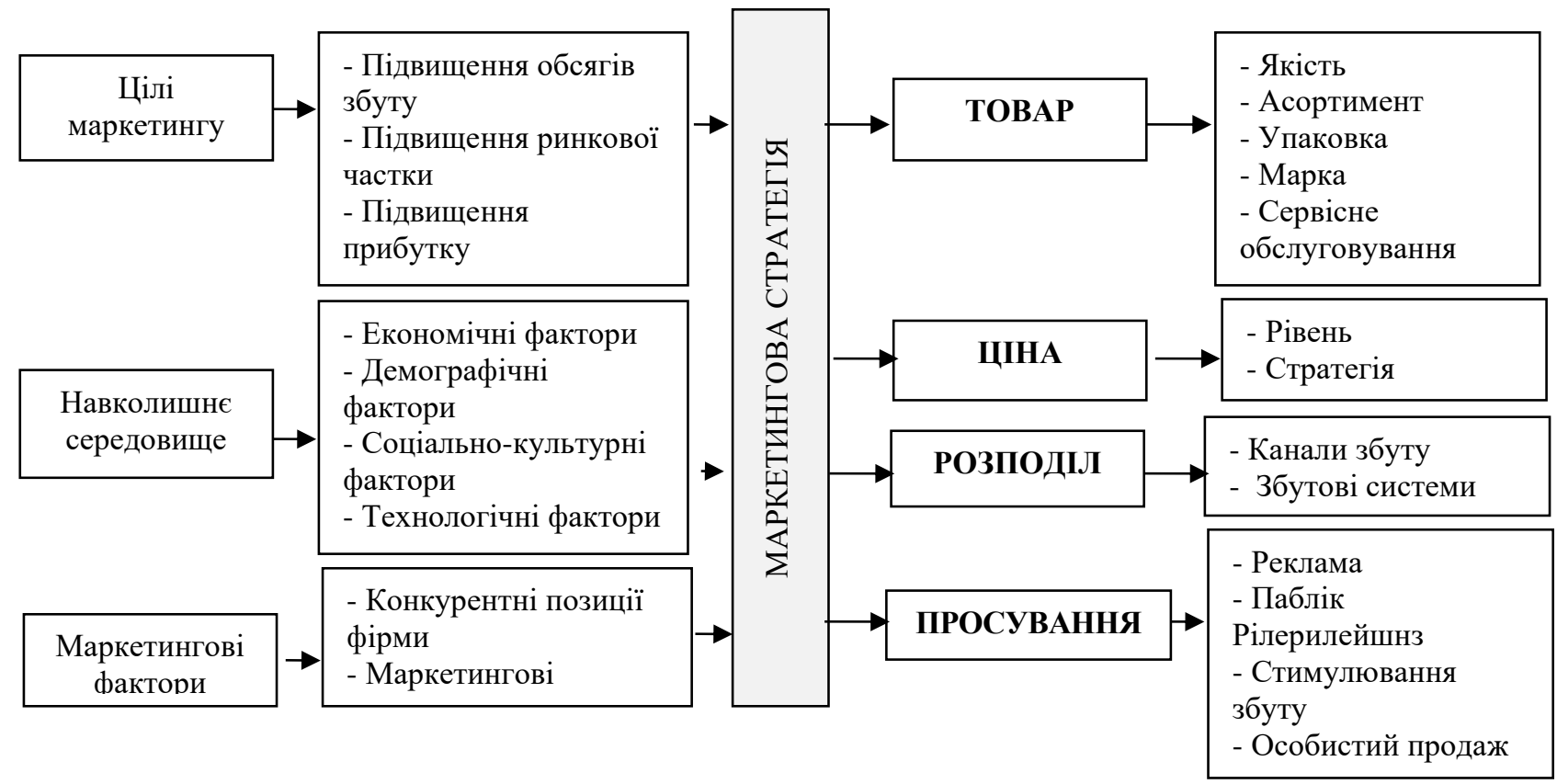

Джерело: [1]

Рис. 1. Елементи маркетингової стратегії підприємства

Таким чином, з наведених вище визначень можна стверджувати, що маркетингова стратегія - це процес, що може дозволити підприємству сконцентрувати свої обмежені можливості на найбільші можливості для збільшення продажів і досягнення стійких конкурентних переваг.

У цілому маркетингова стратегія - це заява про те, що хоче стабільно отримувати підприємство в доступній для огляду перспективі.

Концептуально маркетингову стратегію зазвичай представляють у формі стратегічних рішень щодо маркетингового міксу, тобто комплексу компонентів маркетингу, який включає п'ять складових («5P маркетингу»): товари і послуги (Product), місце чи система розподілу (Place), ціна (Price), просування (Promotion), позиціонування (Positioning). Цілком очевидно, що зазначений концептуальний підхід зумовлює лише окреслення базових компонентів маркетингової стратегії, деталізація яких залежить від особливостей продукції, ії виробництва, сприйняття споживачем тощо.

Вітчизняне бурякоцукрове виробництво залишається одним зі стратегічно важливих напрямів агропромислового комплексу та на сьогодні зберігає перспективи стабілізації попри певні проблемні аспекти у розвитку галузі в цілому.

Динаміку посівних площ цукрового буряку в Україні представимо на рисунку 2.

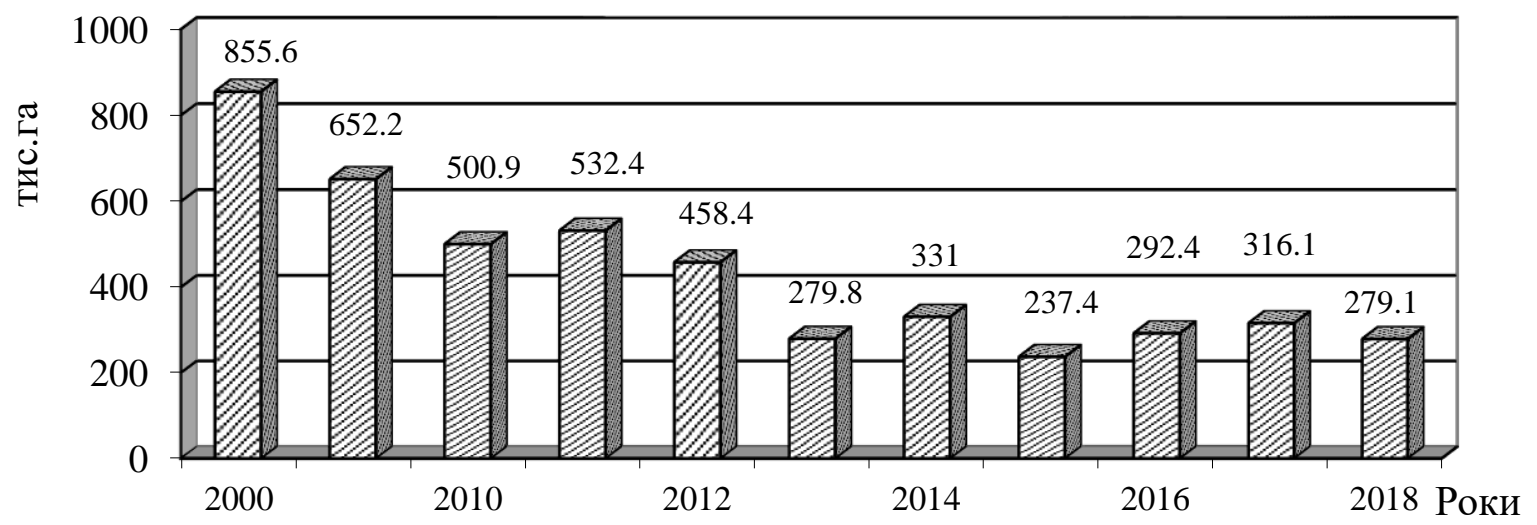

Рис. 2. Динаміка посівних площ цукрових буряків в усіх категоріях господарств Украӥни,

Джерело: [15]

тис.га.

Внаслідок переорієнтації вітчизняних цукровиробників на розвиток експорту цукру, а також деякою мірою і через вплив інтенсифікації виробництва, відбувається скорочення посівних площ під цукровими буряками (фабричними) в усіх категоріях господарств. Свідченням цього є 
зменшення площі посівів під цукровими буряками в Україні за період 2000-2018 рр. на 32,6\% або на 576,5 тис. га.

Потужний вплив на стан і динаміку розвитку бурякоцукрової галузі останніми роками справляє показник загального обсягу виробництва цукрової сировини та рівень ії цукристості. Перший залежить від розміру посівних площ і середньої урожайності вирощування культури, тоді як другий показник визначається безпосередньо тенденцією порівняно ширшого використання нових високопродуктивних гібридів цукрового буряку вітчизняної й іноземної селекції, особливо новітнього покоління, що мають досить високий потенціал урожайності і цукристості, а також переходу багатьох господарств на інтенсивні технології його вирощування.

Так, наслідком інтенсифікації цукровиробництва $є$ те, що через скорочення посівних площ не спостерігається зменшення валових зборів цукрових буряків. За останні десять років спостерігаються чіткі позитивні зміни, а саме: при скороченні посівних площ поступово зростає валовий збір за рахунок підвищення урожайності цукрових буряків (рис. 3).

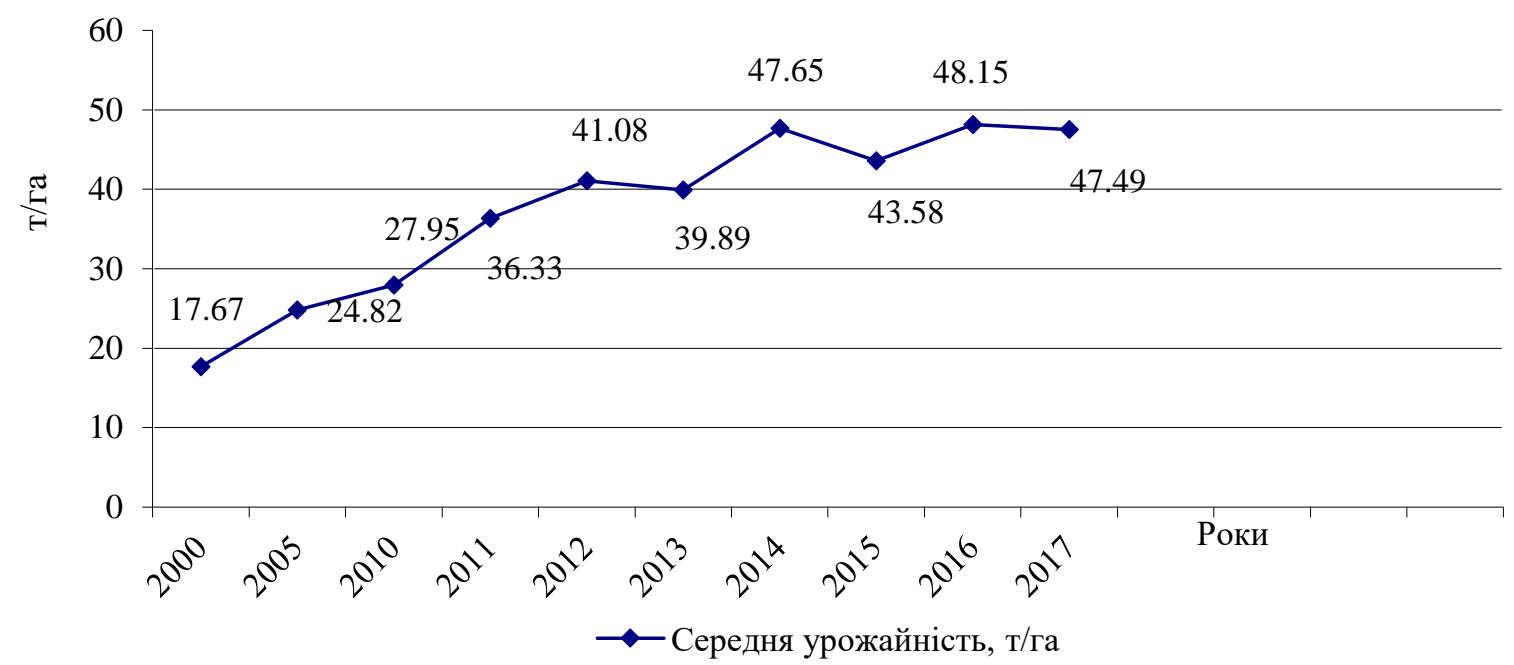

Джерело: [15]

Рис. 3. Динаміка урожайності цукрових буряків в Україні

Дані рисунка 3 підтверджують висновок про те, що середня урожайність коренеплодів в Україні починаючи з 2000 року набрала чіткої тенденції до зростання, що дає можливість навіть при меншій площі збирання досягнути кращих результатів. Особливо високого рівня середньої урожайності було досягнуто у 2016 році - 48,15 т/га, тоді як у 2000 році - лише 17,67т/га. Амплітуда коливань становить - 30,48 т/га.

У бурякоцукровому підкомплексі України відбулася низка серйозних кризових явищ, які характеризуються значними зрушеннями, які в цілому свідчать про певну стабілізацію ситуації та адаптацію іiі до ринкових умов. Ефективність виробництва бурякоцукрового підкомплексу представлено у таблиці 1.

Показники ефективність виробництва бурякоцукрового підкомплексу України

\begin{tabular}{|c|c|c|c|c|}
\hline Роки & $\begin{array}{c}\text { Зібрана площа, } \\
\text { тис.га }\end{array}$ & $\begin{array}{c}\text { Валовий збір, } \\
\text { тис.т }\end{array}$ & $\begin{array}{c}\text { Виробництво цукру, } \\
\text { тис.т }\end{array}$ & Рівень цукристості,\% \\
\hline 2000 & 747,0 & 13198,8 & 1552,0 & 11,8 \\
\hline 2005 & 623,3 & 15467,8 & 1900,0 & 12,3 \\
\hline 2010 & 492,0 & 13749,2 & 1546,2 & 11,2 \\
\hline 2011 & 515,8 & 18740,5 & 2326,9 & 11,6 \\
\hline 2012 & 448,9 & 18438,9 & 2143,4 & 11,7 \\
\hline 2013 & 270,5 & 10789,4 & 1261,6 & 13,0 \\
\hline 2014 & 330,2 & 15734,1 & 2053,2 & 14,1 \\
\hline 2015 & 237,0 & 10330,8 & 1459,3 & 13,3 \\
\hline 2016 & 291,1 & 14011,3 & 1997,0 & 13,8 \\
\hline 2017 & 313,6 & 14881,4 & 2042,6 & 1820,0 \\
\hline 2018 & 280,0 & 14490,0 & & \\
\hline
\end{tabular}


Дані таблиці свідчать, що виробництво цукру за останні роки дещо стабілізувалось порявняно з попередніми роками, рівень цукристості в середньому збільшився і становить 13-14\%.

Внутрішній ринок цукру України оцінюється в 1,2-1,3 млн. тон. Українськими підприємствами в січні-травні 2019 року реалізовано 326,9 тис. тон бурякового цукру білого (-1,5\% до 2018 р.). Середня ціна реалізації цукру склала 8942,3 грн за тонну, що на 3,7\% менше, ніж у 2018 році. Ціна вказана без ПДВ, дотацій, транспортних, експедиційних та накладних витрат [14].

За даними НАЦУ «Укрцукор» у 2018/2019 МР працювало 42 цукрових заводи, які виготовили 182 млн.т цукру і переробили 13,6 млн.т цукрових буряків, в 2019/2020МР працюватиме 34 цукрових заводи, а виробництво очікується на рівні 1,1-1,2 млн. т цукру [15].

Одним зі стратегічних напрямів розвитку бурякоцукрової галузі за умов скорочення внутрішнього попиту є переорієнтація продукції на експорт та пошук нових каналів збуту готової продукції - цукру.

Тому, на нашу думку кожна окрема маркетингова стратегія повинна передбачати організацію процесу ії реалізації, що поєднує окремі сегменти маркетингової політики, які відповідають базовим складовим маркетингової стратегії. Отож, побудова ефективної маркетингової стратегії зумовлює необхідність детелізації іï окремих компонентів у контексті особливостей функціонування того чи іншого підприємства.

Прискорення розвитку ринку вимагає інтегрування не тільки видів, каналів, типів маркетингових комунікації, а й засобів і методів, яких застосовують для досягнення поставлених цілей підприємства. Об'єднання різних інструментів маркетингових комунікацій надає можливості отримання синергетичного ефекту за рахунок об'єднання позитивних якостей кожного елемента i появи нового результату, яким не володіє кожен з компонентів інтегрованих маркетингових комунікацій окремо.

Більшість зарубіжних та українських підприємств не нехтують можливістю використання інтеграції у своїй маркетинговій діяльності. У якості нового і важливого інструменту розробки маркетингової стратегії підприємства виступають (розглядаються) технології інтегрування комунікативних механізмів. Підприємства, які правильно будують стратегічні плани і бюджет маркетингових комунікацій, досягають кращих результатів.

На рисунку 4 представлено інтегровану модель маркетингової стратегії підприємств бурякоцукрового підкомплексу, яка концептуально поєднує основні ії складові.

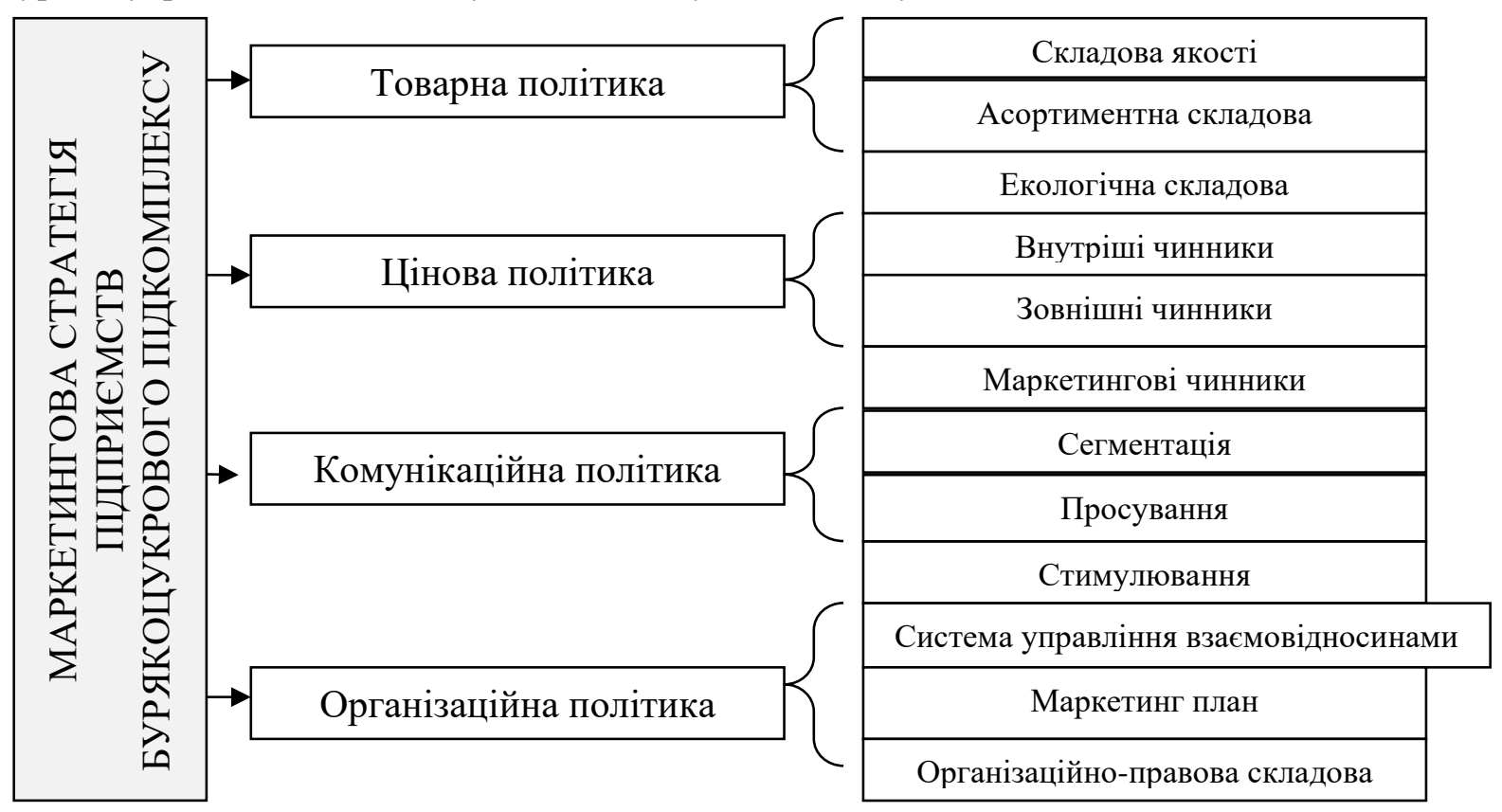

Рис. 4. Інтегрована модель маркетингової стратегії підприємства

Джерело: Власна розробка

Очевидно, що грунтовний аналіз кожної з них передбачає їхнє детальне опрацювання та огляд в контексті функціонування окремих груп підприємств, враховуючи специфіку продукції бурякоцукрового підкомплексу та процесу іiі виробництва, що має вагомий вплив на їх маркетингову стратегію. 
Тому, інтегрована модель маркетингової стратегії для основної продукції підприємств бурякоцукрового підкомплексу - цукру, спрямована на ефективний взаємозв'язок основних іiі складових - товарної, цінової, комунікаційної, організаційної політики 3 врахуванням маркетингових складових:

1) Товарна політика підприємств бурякоцукрового підкомплексу країни повинна бути орієнтована на постійне покращення якості продукції як один із пріоритетних напрямів діяльності цукрового заводу, що забезпечує його конкурентні переваги на ринку. Асортиментна складова передбачає комплексне застосування диверсифікації товарного виробництва шляхом удосконалення існуючого асортименту та переробки побічної продукції. Оскільки бурякоцукрові підприємства зумовлюють переробку сировини із застосуванням великих обсягів води, що потенційно має вагомий деструктивний вплив на навколишнє природне середовище, то закцентуємо увагу саме на екологічній складовій їх товарної політики.

2) Цінова політика підприємства $є$ комплексом заходів щодо процесу ціноутворення на підприємствах бурякоцукрової галузі, які мають бути зорієнтовані на максимальне задоволення потреб споживачів та отримання бажаного прибутку від реалізації продукції на ринку. Заходи розробляються відповідно до принципів, правил і критеріїв маркетингу. При їх розробці зважають на особливості формування прогнозного рівня ціни на продукцію, коригування ціни згідно з реальним попитом на основі застосування системи знижок (надбавок), визначення умов оплати, використання контролю за цінами. Також передбачається використання прямих $\mathrm{i}$ непрямих методів маркетингового ціноутворення. При встановленні цін підприємство враховує щонайменше три чинники:

-ціни повинні перевищувати собівартість, оскільки тільки в цьому випадку може бути отриманий прибуток;

-ціни повинні враховувати поведінку покупця стосовно пропонованої ціни;

-ціни повинні враховувати поведінку конкурентів на ринку товарів.

3. Більшість маркетологів зазчачають, що застосування концепції інтегрованих маркетингових комунікацій забезпечує більш повне задоволення стратегічних цілей підприємств. Для успішного застосування стратегії інтегрованих маркетингових комунікацій необхідне централізоване інтегрування основних зусиль для просування товару відповідно до стратегії його позиціонування. Тому використання комунікаційної політики передбачає створення позитивного іміджу підприємств бурякоцукрового підкомплексу країни вцілому з застосування стимулюючих заходів, розроблення та впровадження єдиної маркетингової комунікаційної програми на сучасних підприємствах, що дозволяє повноцінно використовувати всі засоби маркетингових комунікацій у комплексі з метою збільшення обсягів реалізації готової продукції.

4. Важливим елементом маркетингової стратегії підприємств бурякоцукрового підкомплексу $€$ організаційна політика 3 найважливішими функціями управління підприємством, поряд 3 такими, як фінанси, облік господарських операцій, управління персоналом [16]. Бурякоцукровий підкомплекс України досить складна організаційно-господарська спеціалізована структура, в якій окремі організаційно-правові суб'єкти взаємозалежні технологічно і економічно. Предметом маркетинг плану $\epsilon$ стратегія відродження бурякоцукрового підкомплексу, обгрунтування доцільності виведення відповідних продуктів за вимогами цільових ринків, що є ключовим фактором успіху галузі та відкриває перспективи конкурентних позицій.

Висновки. Проблема формування i розвитку маркетингових стратегій підприємств знаходиться поряд із найбільш важливими теоретичними і практичними аспектами економічного розвитку. Проте, проведені дослідження показують, що головним фактором, який перешкоджає ефективній маркетинговій діяльності підприємств, є їхня недостатня розробка або взагалі іiі відсутність. Це пов'язано не тільки 3 масштабністю і складністю розв'язуваних економічних і технологічних задач, а й спробами значної частини керівників вирішувати принципово нові завдання й виклики старими методами.

Ефективне функціонування бурякоцукрового підкомплексу передбачає тісну інтеграцію його сфер та їхню збалансованість, тому формування інтегрованої маркетингової стратегії для бурякоцукрового підкомплексу повинна використовуватись різними підприємствами, компаніями, фірмами для співпраці зі своїми споживачами, а також для інформування клієнтів про особливості, технічні характеристики та переваги своїх продуктів. Вона спрямована на те, щоб спонукати цільову групу населення купувати стратегічно важливі продукти - цукор.

У результаті цього очевидною $є$ необхідність розробки маркетингових стратегій підприємств цукробурякової промисловості, які враховують специфіку української економічної практики, заснованої на передовому досвіді економічно розвинених країн. 


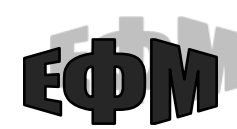

http://efm.vsau.org/

\section{Список використаних джерел:}

1. Куденко Н.В. Стратегічний маркетинг : навч. посіб. Київ : Знання, 2005. 152 с.

2. Ламбен Ж.Ж. Стратегический маркетинг. Европейская перспектива / пер. 3 франц. Б. Лифляндчик и др. С-Петербург : Наука, 1996. 589 с.

3. Гаркавенко С.С. Маркетинг : навч.посіб. Київ, 2003. 382 с.

4. Анисимов О.С. Стратегия и стратегическое мышление. Вопросы методологи. 2009. № 1-2. C. $114-130$.

5. Балабанова Л.В., Холод В.В., Балабанова І.В. Стратегічний маркетинг : підручник. Київ, : Центр учбової літератури, 2012. $630 \mathrm{c}$.

6. Григор А.В. Исследование инструментальных стратегий маркетинга. Актуальні проблеми економіки. 2015. № 2 (44). С. 47-52.

7. Алферов А. В. Методи маркетингової діяльності. СПб.: СПбГІЕУ, 2004. 155 с

8. Коваль 3.О. Поняття і сутність ефективності маркетингових стратегій вартісноорієнтованих підприємств. Видавництвво “Львівська політехніка”. 2012. № 722. URL: http://vlp.com.ua/node/8626 (дата звернення: 12. 08. 2019).

9. Масляк Т.А. Формування маркетингової стратегії на підприємстві. Управління розвитком. 2012. № 2. С. 50-52.

10. Беляевский И. К. Маркетинговое исследование. Информация, анализ, прогноз : учебное пособие. Москва : Финансы и статистика, 2014. 320 c. URL: IPRbooks (дата звернення: 18.08.2019).

11. Котлер Ф. Основи маркетингу : учеб. пособие / пер. с англ. В.Б. Боброва. Москва, 2012. 751 с.

12. Котлер Ф. Основы маркетинга. Москва : Издательский дом "Вильямс", 2007. 656 с.

13. Хершген Х. Маркетинг - основы профессионального успеха : учеб. пособие / пер.с нем. Х. Хершген. Москва: ИНФРА-М, 2000. 334 с.

14. Стратегія розвитку аграрного сектору економіки на період до 2020 року / М-во аграр. політики та продовольства України. URL: https://zakon.rada.gov.ua/laws/show/806-2013 (дата звернення: 18.08.2019).

15. Аналітична довідка. Сезон цукроваріння 2019/2020 MP URL: http://ukrsugar.com/uk

16. Калетнік Г.М. Інноваційні моделі управління стратегічним економічним потенціалом сучасних економічних систем. Актуальні проблеми економіки. 2011. №4. С. 3-11.

\section{References}

1. Kudenko, N.B. (2005). Stratehchnyi marketynhg [Strategic Marketing]. Kyiv: Znannia [in Ukrainian].

2. Lamber Zh.Zh. Strategicheskij marketing. Evropejskaya perspektiva [Strategic marketing. European perspective]. S-Peterburg: Nauka [in Russian]

3. Garkavenko, S.S. (2003). Marketyng [Marketyng]. Kyiv: [in Ukrainian].

4. Anisimov, O.S. (2009) Strategia I strategicheskoe myshleniy [Strategy and Strategic Thinking]. Voprosu metodologii - Methodology issues, 1-2, 114-130 [in Russian].

5.Balabanova, L.V., \& Kholod, V.V., \& Balabanova, I.V. (2012). Strategichyi marketing [Strategic Marketing]. Kyiv: Tsentr uchbovoi [in Ukrainian].

6. Hryhor, A.V. (2015). Isledovayie instrumentalnykh stratehii marketinga [Research Instrumental Marketing Strategies]. Aktualni problem ekonomiky - Current problems of the economy, 2, 47-52 [in Ukrainian].

7. Aiferov A.V. (2004). Metodu marketynhovoi diyalnosti [Methods of marketing activity]. SPbGIEU [in Russian].

8. Koval T.A. (2012). Poniattia I sutnist efektyvnosti marketynhgovykh strategii vartisnooriientovanyh pidpryiemstv [The concept and essence of the effectiveness of marketing strategies of valueoriented enterprises]. Lvivska politekhnika - Lviv Polytechnic, 722, 99-104. Retrieved from http://vlp.com.ua/node/8626 [in Ukrainian].

9. Masliak, T.A. (2012). Formuvannia marketynhovoi stratehii na pidpryiemstvi [Formation of marketing strategy at the enterprise]. Upravlinnia pozvytkom - Development Management, 2, 50-52 [in Ukrainian].

10. Beliavskii, I.K. (2014). Marketinhgovoe isledovanie. Informatsiia, analiz, prohgnoz [Marketing research. Information, analysis, forecast]. Moskva: Finansy i statistika. Retrieved from IPRbooks

11. Kotler, F. (2012). Osnovy marketinga [Principles of Marketing]. (V.B. Bobrova, Trans). Moskva [in Russian].

12. Kotler, F. (2007). Osnovy marketinga [Principles of Marketing]. Moskva : Izdatelskij dom "Vil'yams" [in Russian].

13. Khrshhgen, Kh. (2000). Marketyng - osnovy profisionalnohgo uspekha [Marketing - the basics of professional success]. (Kh. Khrshhgen, Trans). Moskva: INFRA-M [in Russian]. 
14. Stratehgiia pozvytku ahgrarnohgo sektoru ekonomiky na period do 2020 roku [Strategy for the development of the agricultural sector of the economy until 2020]. (n.d.). zakon.rada.gov.ua Retrieved from https://zakon.rada.gov.ua/laws/show/806-2013 [in Ukrainian].

15. Analitychna dovidka. Sezon Tsukrovarinnia 2019/2020 MR (2019). [Sugar Sugar Season 2019/2020 MR]. (n.d.). ukrsugar.com/uk Retrieved from http://ukrsugar.com/uk [in Ukrainian].

16. Kaletnik H.M. (2011). Innovatsiini modeli upravlinnia stratehichnym ekonomichnym potentsialom suchasnykh ekonomichnykh system [Innovative models of management of strategic economic potential of modern economic systems]. Aktualni problemy ekonomiky - Actual problems of the economy, 4, 3-11 [in Ukrainian].

\section{Інформація про авторів}

КРАСНЯК Олена Петрівна - кандидат економічних наук, доцент кафедри маркетингу та аграрного бізнесу, Вінницький національний аграрний університет (21008, м. Вінниця, вул. Сонячна, 3, e-mail: lenakrasnyak@gmail.com).

АМОНС Сергій Едуардович - кандидат сільськогосподарських наук, доцент кафедри маркетингу та аграрного бізнесу, Вінницький національний аграрний університет (21008, м. Вінниця, вул. Сонячна, 3, e-mail: sergeyamons@gmail.com).

KRFSNIAK Olena - Candidate of Economical Science, Associate Professor of the Department of Marketing and Agrarian Business, Vinnitsia National Agrarian University (21008, Vinnytsia, 3, Soniachna Str., e-mail: lenakrasnyak@gmail.com).

AMONS Sergey - Candidate of Agricultural Sciences, Associate Professor,Associate Professor of the Department of Marketing and Agrarian Business, Vinnytsia National Agrarian University (21008, Vinnytsia, 3, Soniachna Str., e-mail: sergeyamons@gmail.com).

КРАСНЯК Елена Петровна - кандидат экономических наук, доцент кафедры маркетинга и аграрного бизнеса, Винницкий национальный аграрный университет $(21008$, г. Винница, ул. Солнечная, 3, e-mail: lenakrasnyak@ gmail.com).

АМОНС Сергей Эдуардович - кандидат сельскохозяйственных наук, доцент кафедры экономики, Винницкий национальный аграрный университет (21008, г. Винница, ул. Солнечная, 3 , e-mail: sergeyamons@gmail.com). 